の前途岁和予測しえならはどの発展性を示してい る.

\section{4. 应用}

前述のように硝子織維補強樹脂は軽量で，しかも金 属儿優る強度を持ち, 大型製品への成形加工も容易で あるばかりでねく，金属あるいは木材などの他の棈造 材料の持をない幾多の特徴を兼ね具えているので，今 日ではこの補強樹脂製品はこれらの代替品としてでな く,全く新しい構造材料としての用途を開拓している.

たと豆ば前述のレードームは航空機に塔戴する電波 兵器の極超短波を透過するばかりでなく，航空機の構 造材の一部として使用され本材料によつて初めて可能 となつをものである，

まを自動車のボディーとして使用する時は金属より も衝撃に強的のて衝突などの事故による損倠も少な く，かつ修理も簡単に行ららる便がある。したがつて アメリカイ和にても濑次スポーツ・カーあたりから本 格的生産に移りつつある状況である。

また海軍用舟艇として戦争中から研究せられ，成形， 修理が容易であり海水によつて腐蝕しない特徴によつ てとの方面への需用はさらに大型艇に及びつつある。 民需用としてるボート、ヨットなどが作られ，最近我 が国でも二三試作せられた。

硝子瀻維補㧧樹脂は衝撃によるエネルギー吸収量が 他の材料比べて著しく大きいので防弾チョッキが大 戦中から試作せられた。このものは小銃などの直撃に は耐充ないが、ピストル，砲弾などの破片には十分耐 えるので朝篻戦線に和けるアメリカ軍の死傷を著しく
軽惐したと言われている。

プリフォーム法による大量生库法が発達してから， との方法による製品としては各種の保安帽、電気洗濯 器槽, 冷蔵庫, 風呂槽なぞが多数作られている.

さらにアメリカイ和にては既に一千万本以上の釣笋 が製造せられまたグライダー翼，スキー、樰などが 作られている.

\section{5. 結言}

以上簡単に硝子䊼維補強樹脂の概観につ々て述べた が、本工業はアメリカに和にてもなま発展途上にある ものであり，大量生産法の確立と価格の低下によつて さらに大をな用途の開拓を目指しているをたとえば一 方《和々ては硬化速度の速的樹脂組成を求め, 大量生 産成形加工法を改良するととにより価格の低下を求め るとともに，他方に和いては超音速ジェット機，誘道 兵器の構造材としてより表面摩擦による高熱に耐え， 高速に和ける雨滴による侵蝕に耐えるぬどの堌大する 性能への要求に答えるべく大規模な研究が行われつつ ある.

我が国に叔々て昨年は各種製品の試作期であつた が，本年とそは遂次生産へと移行するものと思われ， 硝子緎維補强樹脂時代を現出するのす遠らととでない と思われる。

ただし硝子緎維は国内で十分生産可能であるにかか わらず,ポリエステルの一部原料はェチレン系である ために価格的に当分の間輸入にまつととをよをるくさ れるととと思われ，乙の点国産原料による低圧成形樹 脂の出現が望まれる次第である。

\title{
金属の疲労強度における寸法効果についで
}

金属材料の疲労試験に和にて, 訊験片の寸法が大き くなると、それにつれて痩労強度が减少する傾问のあ るととはすでに古くから知られている。したがつて標 準寸法の試験片で疲労試験を行に,その結果をるとに して寸法の大きな機械部分を設計するならば，疲労強 度が充分でなく，伦険をとるならとととなる。乙の耐 久限度の変化を寸生効果といル，最近とくに注目され

* 原摘受付 䧂和29年 1 月22日

** 正員 京都大學工學部㙨的工舉教室

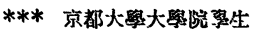

河本実** 秦本謙 一***

てきて和り，乙れを明らか的するをめ大型疲労試験機 なども作られ，実物大の寸法の試験片による疲労試験 が行われるよらとなつてきた。

従来の耐久限度の寸法勃果の実験はその殆どが回転 曲げ疲労試験によつたものであり, 引張圧繀疲労試験 くよるものは極めて少ない。また実験された試験片の 寸法は殆どが植径約 $60 \mathrm{~mm}$ 以下で，それ以上の大をな 試験片につレて実験されたものは極めてまれである。 とくに直径 $30 \mathrm{~mm}$ 以下の小さい寸法に対するものが最 も多らようである。 
耐久限度ぶ試験片寸法の増加につれていかに変化す るかという問題に全面的な解決を与えるととは今のと ころ極めて困難である. 何となれば, この寸法効果の 現象は, 単に材料の盾類のみによつて影響されるもの ではなく、その試験片の表面仕上の程度, 䓡処理法, 加工法, 素材よりの試験片の採取位置, または大型和 よび小型試験片に和りる温度上昇の相違などにより大 きな影響を受けるからである。また熱処理和よで試験 片の採取位置を大型和よび小型試験片にて完全に一致 せしめるととる極めて团難なるためである．したがつ て耐久限度飞寸法効果の生ずる原因を解明するととも なかなかむつかしい問題である．また寸法勃果による 耐久限度の変化は比較的小さく, 罣なつた研究者によ つてなされた実験結果はかぬり相違しているがとれ ら各研究者による実験はその方法, 試験片の種類など レろらろな条件が異なつているので，てれらを互いに

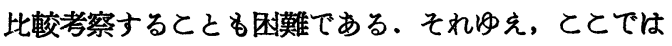
単に耐久限度の寸法勃果につを従来行われた数々の実

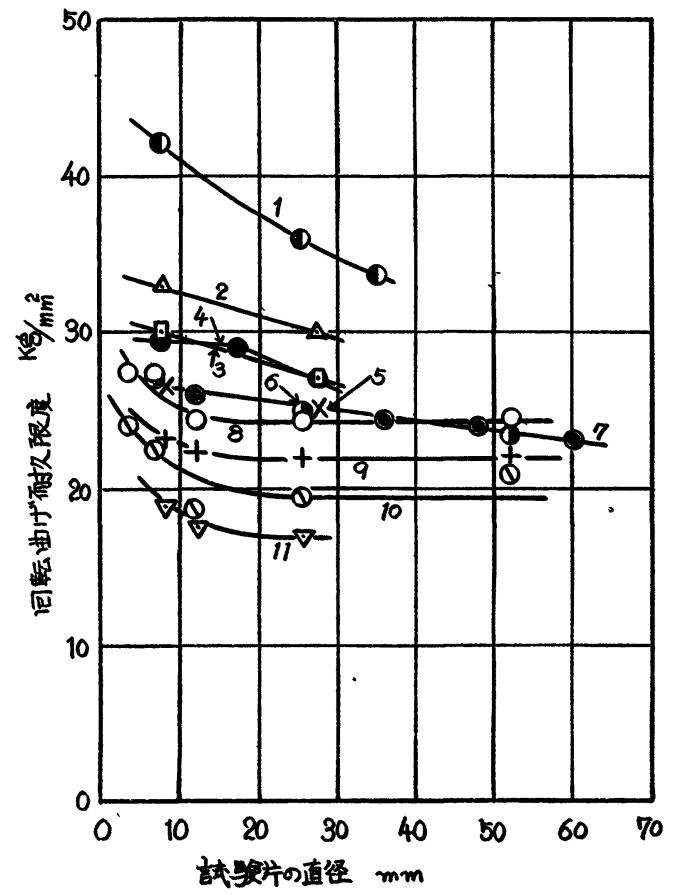

1. $C=0.46 \% \sigma_{B}=86 \mathrm{~kg} / \mathrm{mm}^{2}$ (E. Lehr) $\left.{ }^{2}\right)$

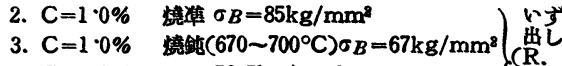

4. $\mathrm{C}=0.3 \% \quad \sigma B=56.5 \mathrm{~kg} / \mathrm{mm}^{2}$

5. $\mathrm{C}=0.1 \% \quad \sigma_{B}=41 \cdot 5 \mathrm{~kg} / \mathrm{mm}^{2}$

6. $\mathrm{C}=0.45 \%$ 焼凖, 引报 (R.E. Peterson) ${ }^{3}$ )

7. $\mathrm{C}=0.35 \%$ 㯖準 $\left(855^{\circ} \mathrm{C}\right.$ ) $\sigma_{B}=55 \cdot 8 \mathrm{~kg} / \mathrm{mm}^{2}$ (小野籃正, 田川 次郎)"

8. $\mathrm{C}=0.34 \% \quad \sigma_{B}=61 \cdot 8 \mathrm{~kg} / \mathrm{mm}^{2}$ (H.F. Moore) ${ }^{5}$ )

9. $\mathrm{C}=0.45 \%$ 燒集 (R.E. Peterson) $)^{3}$ )

10. $C=0 \cdot 22 \% \sigma_{B}=43 \cdot 7 \mathrm{~kg} / \mathrm{mm}^{2}$ (H.F. Moore)5)

11. $\mathrm{C}=0 \cdot 19 \%$ (R.E. Peterson) $)^{3}$ )

第 1 図 炭素鋼の回転曲げ疲労試験に叔りる 寸法効果
験結果を展望することとする。

\section{1. 回転曲げ試験における寸法効果}

a. 炭素䤡の寸法効果 （i）平骨試験片 第 1 図 は回転曲げ試験における㟶素鋼平滑試験片の寸法効果 を示す，図より，試験片の寸法の増加につ礼て耐久限 度が減少する傾向のあるととがわかる，この耐久限度 の減少する割合, すねわち減少率は試験片寸法の小さ レととろでは比較牨大きく，于法の増加につれて次第 に小さくなり，耐久限度は遂にある一定值に近づく傾 向があるように思われる.とくに H.F. Moore \& D. Morkovin ${ }^{5}$ ）の実験などにおいてはこの傾向が顕著で ある。

しかし試験片の寸法が增加して，どのくらんの大き されなったとを耐久限度の咸少が終り，一定值になる かというととは試験片の材料，形状，あるいは㷫処理 法, 加工法などにより異なつてくるであろらと思わ れ, この程度の少数の実験結果から一般的な傾向を推 測するととは困難である。

第2図に示した各点は，第1図に和ける各曲線の 10mm の直径に和りる值を基準にとり，これを $100 \%$ とし，百分率であらわしたものである．第2 図による と, 寸法勃果による耐久限度の変化は值径 $10 \mathrm{~mm}$ を基 準として，とれより寸法の大をいものでは 0〜20\%程 度の耐久限度の低下が見られ，10 $\mathrm{mm}$ 以下の試験片に ては逆に 0 20\%程度の耐久限度の増加が見られる。 すなわち実験結果は第2 図の斜線を施した範囲内に大 体かさまつている. 第 2 図は直径 $60 \mathrm{~mm}$ 以下の試験片 につトての実験結果であるが，さらに寸㹤が増加した

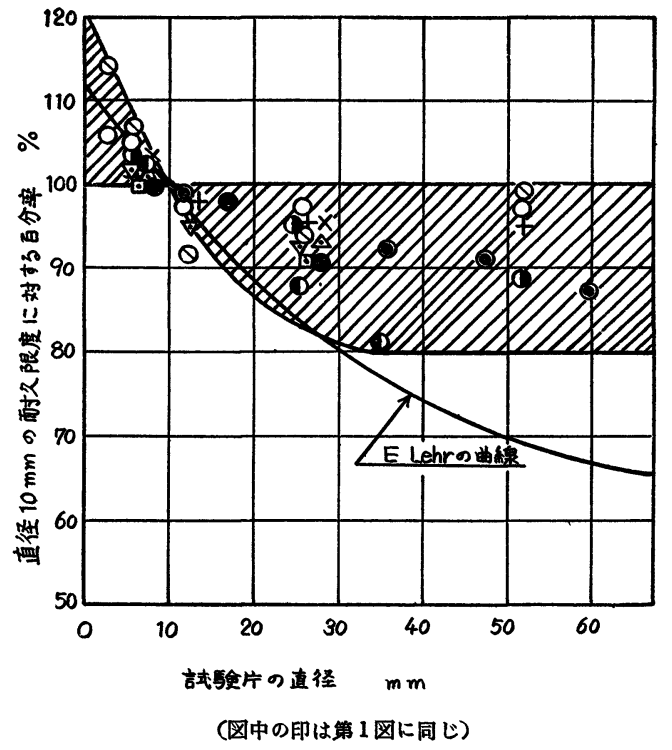

第2 図 宸素鋼平滑試験片の回転曲げ疲労試 験における寸法効果（值径 $10 \mathrm{~mm}$ の耐久限度に対する百分率) 
とき，乙の耐久限度の减少がぞのような傾向をすつか とレらことは，てれだけの実験結果ではもちろん判断 でをないが，とれよりたいして耐久限度が減少するて ともないよう思われる。

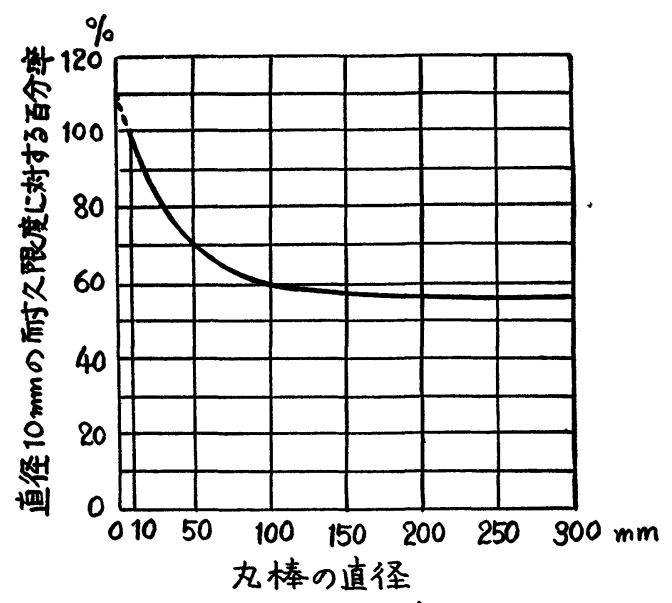

第3 図 E. Lehr ${ }^{6}$ ) そよる炭素鋼の回転曲げ 疲労試験と和ける平滑試験片耐久限 度の寸法効果（值径 $10 \mathrm{~mm}$ の耐久限 度を基準にとつた百分率)

第3 図の曲線はE. Lehr $\left.{ }^{6}\right)$ スるる炭素鋼の回転曲げ 疲労試験に和ける寸法効果をあらわしたもので，上同 様に直径 $10 \mathrm{~mm}$ の試験片を基準にとり，直径 $300 \mathrm{~mm}$ までの平滑試験片について相当広ら範用にわたつて示 したものである。第 2 図中には比較のためての曲線を も併せ示した。 との E. Lehr の曲線によれば, 直径 の大きいとてろでは寸法効果による耐久限度の減少は 相当大をく, 值径 $60 \mathrm{~mm}$ ですでに30\%以上にも達して ロるが，第 2 図に示したごとく実際行われた多くの実 験值ではそのような大をな寸法効果をあらわしている ものは見当らなん。すなわち，かなり安全飞見積つた ののと思われる. しかし一方, 直径のかなり小さんと ころでは, 第 2 図の実験值の方がかえつて寸法効果が 大をく出ているものもあり,必ずしも安全に見積つた ともロ学ないようである。

（ii）切欠試験片 第4 図舛切欠を有する炭素釦試 験片の回転曲げ試験に和ける寸洗効果を示す．図より 切欠試験片に和にてもやはり一般には寸法の大るる場 合注ど耐久限度は減少し，その減少率は寸法の小さに ところでとくに著しく，寸法の增大とともに耐久限度 は底定值に近づく傾向が認められる。しかし中に は寸法の増加により耐久限度が殆ど減少しないるの や，あるには逆に増加するものも認められ，てのとと は特注目すべをととであろう。なお W. Kuntze \& W. Lubimoff ${ }^{1 i}$ ) の実験結果よりわかるどとく，同一 材料では切欠が鋭く，したがつて形状保数 $\boldsymbol{\sigma}_{c}$ の大を

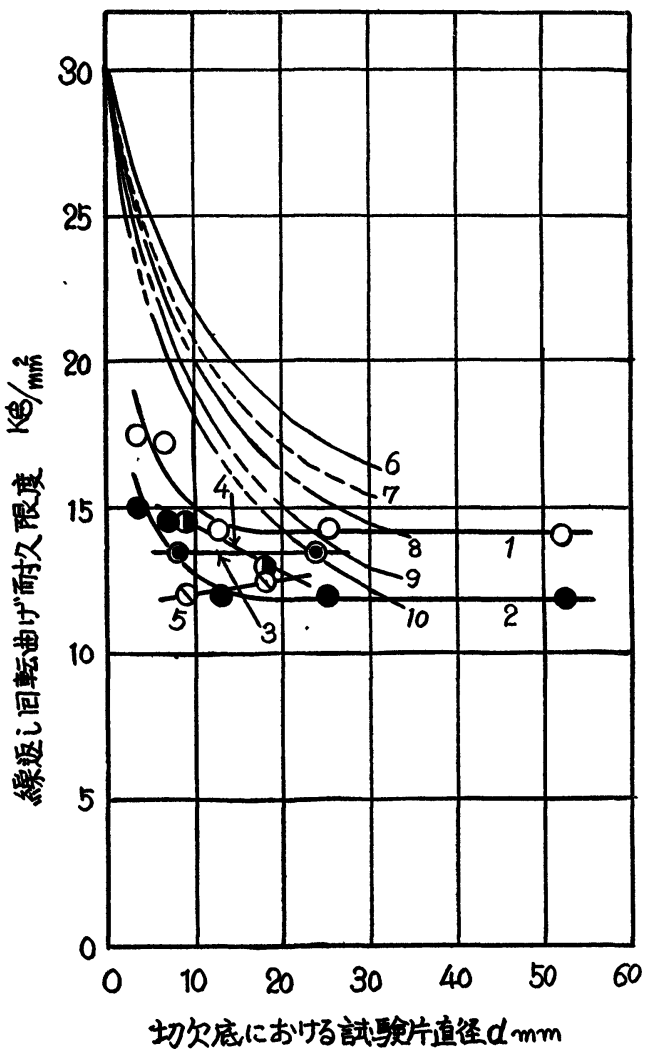

。 : 切欠曲率牛徑

1. 牛图形摆状切欠 $0.34 \%$ 炭素龢

$\rho / d=0.08$ (H.F. Moore-D. Morkcvin) ${ }^{7}$ ) 2. " $0.22 \%$ " $\rho / d=0.08$ ( $"$ " $)^{7)}$

3. 段付切久 $0.34 \% " \prime \rho / d=0.1$ (河本一西岡)

4. $60^{\circ} \mathrm{V}$ 型瑟狀切欠 $0.80 \% " \prime \rho / d=0.02$ (小野 正解) ${ }^{9}$ )

5. " $0.28 \% " \| \quad \rho / d=0.02(\|)$

6. 牛圆形䍙狀切欠 $0.3 \% \quad " 1$ $\rho / d=0.2$ (W. Kuntze-W. Lubimoff $)^{10}$ )

\begin{tabular}{|c|c|c|c|c|c|}
\hline \multirow[t]{2}{*}{7.} & \multirow[t]{2}{*}{$" 1$} & $" \prime$ & & & \\
\hline & & $\rho / d=0.1$ & $" \prime$ & $\prime \prime$ & ) \\
\hline \multirow[t]{2}{*}{8.} & $" \prime$ & $" n$ & & & \\
\hline & & $\dot{\rho} / d=0.05$ & $" \prime$ & $\prime \prime$ & ) \\
\hline \multirow[t]{2}{*}{9.} & $" \prime$ & $" \prime$ & & & \\
\hline & & $\rho / d=0.005 C$ & $\prime \prime$ & $"$ & ) \\
\hline \multirow[t]{2}{*}{10.} & $" \prime$ & $" \prime$ & & & \\
\hline & & $\rho / d=0.002($ & $" \prime$ & $\prime \prime$ & ) \\
\hline
\end{tabular}

第4図 回転曲げ痩労試験における切欠を有 する崖素釦試験片の寸法效果

に場合ほど寸法勃果は顕著に現われるようである。

b. 特殊鋼の寸法効果 (i) 平滑試験片 第 5 図 は特殊鋼平滑試験片の寸法效果をあらわす．試験片の 寸法增加によつて耐久限度の隇少する割合はやはり寸 法の小さなととろで著しく，寸法の増大ととるに耐久 限度はほぼ一定值に近づくことは前の炭素鋼の場合と 同様である. 第 6 図は前の第 2 図を求めたとをと同様 の方法により，第 5 図の実験值を直径 $10 \mathrm{~mm}$ の試験 片の耐久限度を基準としてて百分率であらわしたもので ある. 図中斜線を施した範囲は前の第2 図に和けるも 


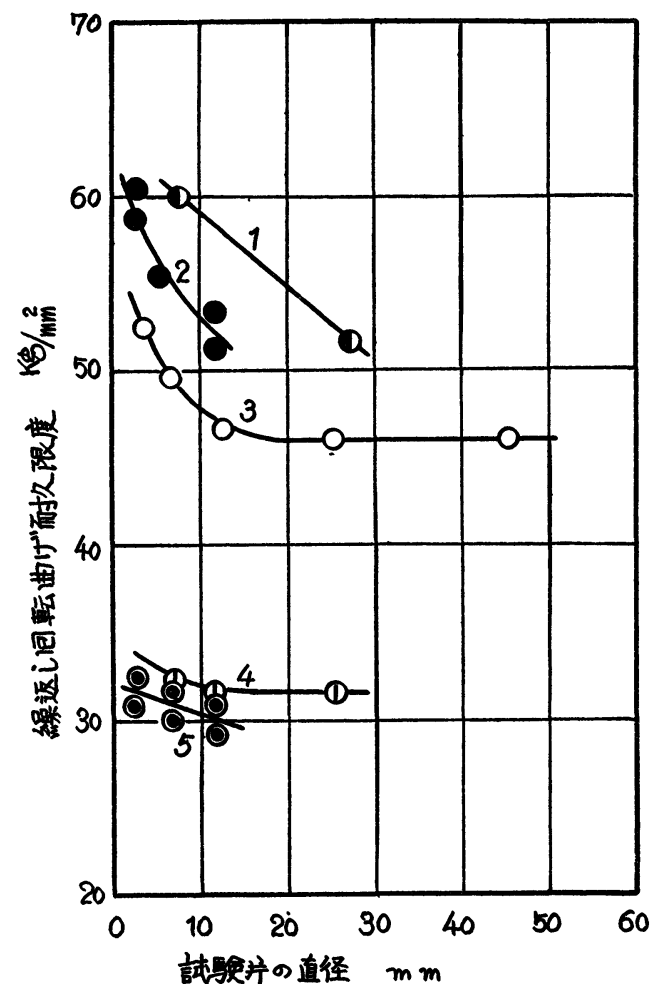

1. $\mathrm{N}_{1} \cdot \mathrm{C}_{I}$ 鋼(VCN 35) $\sigma_{B}=117 \mathrm{~kg} / \mathrm{mm}^{2}$ Dや出し (R. Faulhaber) $\left.)^{2}\right)$

2. $\mathrm{Cr}-\mathrm{MC}$ 銅 $\mathrm{Cr}=0.72 \%, \mathrm{Mo}=0.35 \%, \mathrm{C}=0.39 \%$, $\sigma_{B}=105 \mathrm{~kg} / \mathrm{mm}^{2}$ (H.F. Moore) ${ }^{11}$ )

3. $\mathrm{Cr}-\mathrm{Mo}$ 銅 $\mathrm{Cr}=1.08 \%, \mathrm{Mo}=0.20 \%, \mathrm{C}=0.31 \%$. $\sigma_{B}=99 \cdot 8 \mathrm{~kg} / \mathrm{mm}^{2}$ (H.F. Moore) $\left.)^{5}\right)$

4. $\mathrm{Ni}$ 呤燒集 (R.E. Peterson) $)^{3}$ )

5. 合金銅 $\mathrm{C}=0.08 \%, \mathrm{Mn}=0.37 \%, \mathrm{Si}=0.066 \%, \mathrm{Ni}=0.69 \%$, $\mathrm{Mo}=0.071 \%, \sigma_{B}=47 \mathrm{~kg} / \mathrm{mm}^{2}(\mathrm{HT}-50)$ (H.F. Moore) $)^{11}$ )

第 5 図 回転曲げ疲労試験飞和ける特䛈鋼の寸法効果

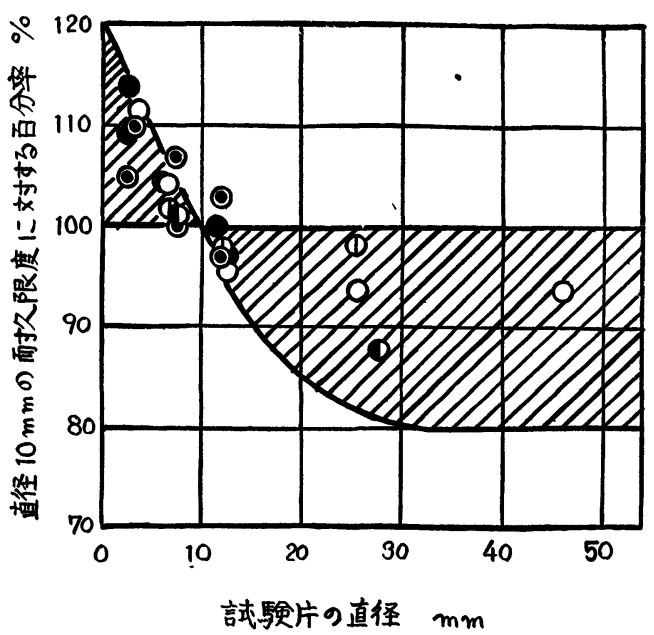

（罒中の印は第 5 図に同じ）

第6 図 特殊鋼の回転曲げ疲労試験に和ける寸法效果 （直径 $10 \mathrm{~mm}$ の耐久限度に対する百分率）
のと全く同一で, 実験結果は二三の例外を除を大体と の輚囲内に和さまつている.

（ii）切欠試験片 第7図は特秼鋼の切欠を有する 試験片の寸法勃果を示している. 実験值は Cr-Mo 鋼 和よび Cr-Ni-W 鋼の 2 つくつけてしか得られす，充 分検討するととがでをない.しかし上述のものと此べ てとくに変つた傾向もあらわれていないようである。

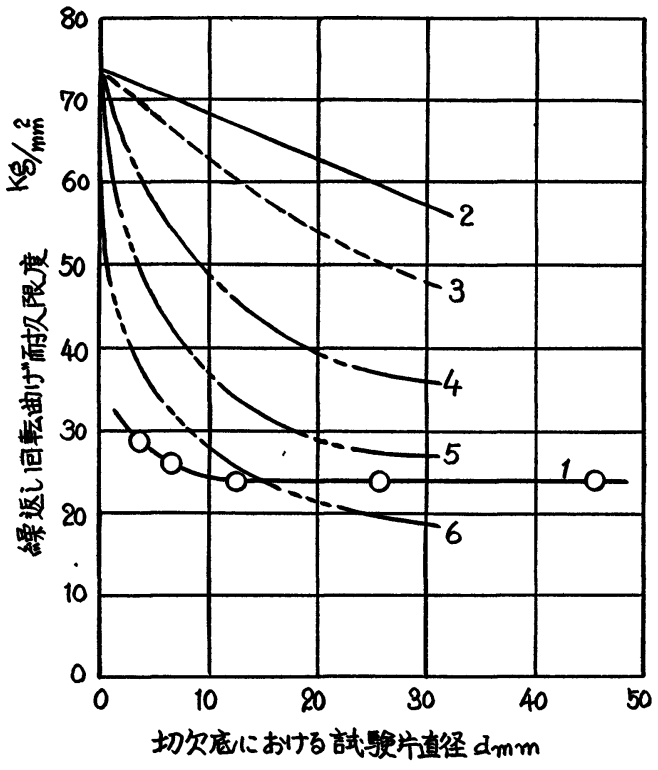
$\rho:$ 切欠曲率牛徑

1. 牛圆形喕狀切久 Cr-Mo 釗 $1.08 \% \mathrm{Cr}, 0.20 \% \mathrm{Mo}, 0.31 \% \mathrm{C}$,

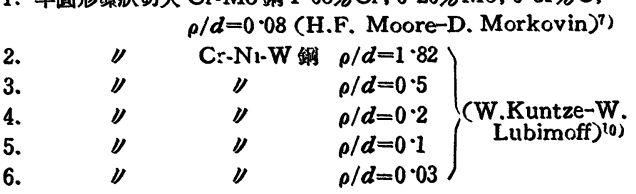

第7図 回転曲げ疲労試験に叔ける切欠を有 する特殊鍴試験片の寸法効果

c. 軽合金における寸法勃果第8図は軽合金の 平滑試験片に対する回転曲げ疲労試験における寸法効 果を示す.軽合金に和々ては実験資料が極めて少なく， したがつて確実なととは知るととができなかが，鉄鋼 の場合とは著しく異なつた傾向を示している。すなわ ち, 試験片值径の増加につれて耐久限度は堌大する かまをは不変となつている，てれは鉄鋼て見られる 一般の寸法効果の傾向とは全く逆で，注目すべをてと と思われる。ただし第 8 図の実験結果はいすれれ直径 約 $10 \mathrm{~mm}$ 以下の細試験片につ々て行われたものであ り，乙か子鉄鋼に和いては，乙の附近の寸法で寸法効 果による耐久限度の减少率が最も大き的とてろである だけK,ととさら注目すべをととであろう・值径 $10 \mathrm{~mm}$ 以上の太々試験片に対する実験結果は見当らないが， さらに寸法の大をな試験片につマても実験を行充ば興 味ある結果か得られるすのと思われる。 


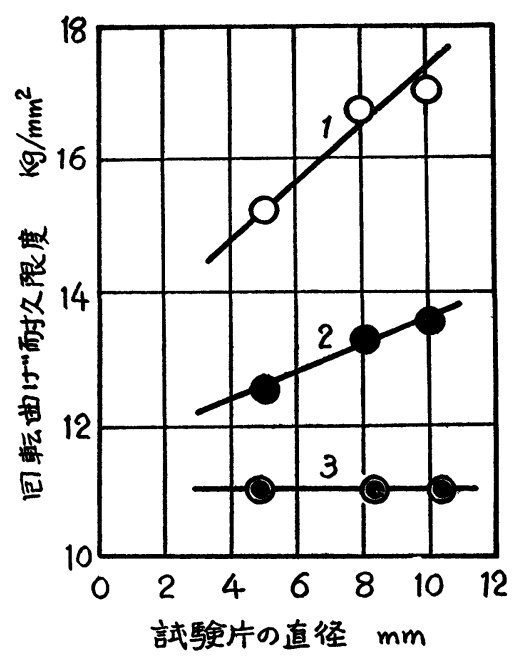

1. 超ジニラルミン $4.40 \% \mathrm{Cu}, 0.59 \% \mathrm{Mn}, 1.45 \% \mathrm{Mg}$, $\sigma_{B}=48 \cdot 7 \mathrm{~kg} / \mathrm{mm}^{2}, H_{B}=118$ (五十崖勇, 梁井誠吉)

2. ジュラルミン $3.47 \% \mathrm{Cu}, 0.45 \% \mathrm{Mn}, 0.46 \% \mathrm{Mg}$, $\sigma_{B}=40 \cdot 8 \mathrm{~kg} / \mathrm{mm}^{2}, H_{B}=103$ (五十嵐勇, 梁井誠吉)

3. ジュラルミン (17S-T) $3.5 \sim 4.5 \% \mathrm{Cu}, 0 \cdot 4 \sim 0 \cdot 1 \% \mathrm{Mn}$, $0.2 \sim 0.75 \% \mathrm{Mg}, \sigma_{B}=40 \mathrm{~kg} / \mathrm{mm}^{2}, H_{B}=95$ (H.F. Moore) ${ }^{1)}$

第8 図 軽合金平滑試験片の回転曲げ度労試 験飞和ける寸法効果

2. 引張圧縮試験における寸法効果

引張圧縮試験と和ける寸法效果を求めを实験結果は ほとんど見当らならようである.第 9 园は M. Hempel ${ }^{13)}$ による平滑試験片に対する実験結果である。これによ

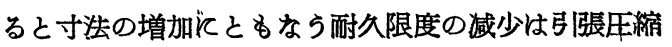
試験汇扣にても非常に大きいととがわかる。

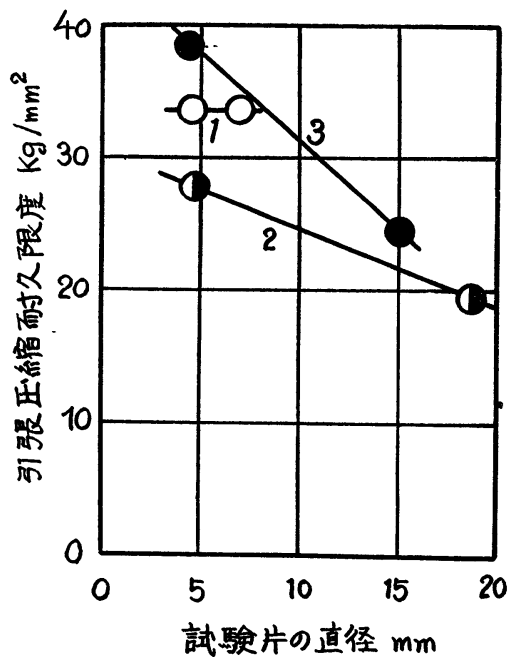

1. St $52\left(\sigma_{B}=59 \cdot 1 \mathrm{~kg} / \mathrm{mm}^{2}\right)$

2. D2 $\left(\sigma_{B}=53 \cdot 0 \mathrm{~kg} / \mathrm{mm}^{2}\right)$

3. D6 $\left(\sigma_{R}=80 \cdot 7 \mathrm{~kg} / \mathrm{mm}^{2}\right)$ (M. Hempel)13)

小型試騟片 $\left(10 \mathrm{~mm}\right.$ 以下) $2600 \mathrm{rpm}, N=10 \times 10^{6}$ 大型試弱片 (10 mm以上) $500 \mathrm{rpm}, N=2 \times 10^{6}$

第 9 図 三張圧縮喥学試験飞和ける平滑試験 片の寸法効果

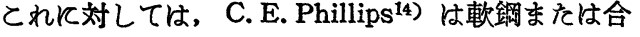
金鋼に和ける平滑試験片の弓張圧縮疲労試験において は，耐久限度に対する寸法効果は殆どないであろうと 述べている。しかして，その理由として回転曲げ疲労 試験による耐久限度の值が引張圧縮試験とよる值に比 してかぬり大きいととから，回転曲げ疲労試験沉から て寸法が次第に大をくなるにつれて，寸法勃果により 耐久限度が減少し，その極限值が引張圧㜚試験沈和け る耐久限度になるものであろらと考元ている。しか し，乙の考充は筆者の一人がすでに発表しているごと

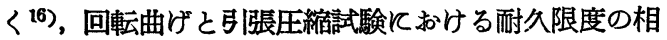
違は, 疲労に伴う材料の非弾性が原因しているものと 考完られ首省し難的。

\section{3. 繰返㨭リ試験における寸法効果}

第10図は R. Mailänder ${ }^{17)}$ が行つた特殊鋼の絽返拚 り試験に和ける寸法勃果の実験結果である。試験片の

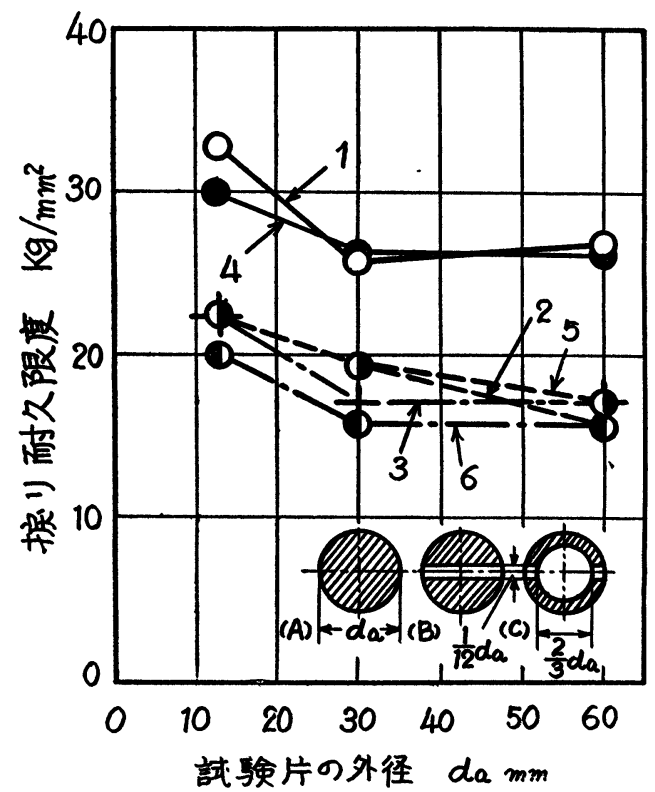

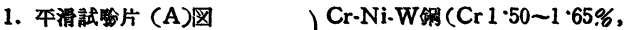

2. 孔有する試驗片 (B)図 Ni $4 \cdot 2 \sim 4 \cdot 3 \%, W 0.98 \%)$

4. 平滑試验片 (A)図) Cr-Ni-Mo-V䍄 (Cr $2 \cdot 46 \%$,

5. 孔有する試呀片 (B)図

$\sigma_{B}=129 \sim 133 \mathrm{~kg} / \mathrm{mm}^{2}$

6. 孔有する中穵試騟片 (C)図) (F. Bollenrath) ${ }^{17}$ )

第10図 特殊鋼の㨝り耐久限度の寸法効果

大をさは外径 $12 \mathrm{~mm}, 30 \mathrm{~mm}$ ，和よび $60 \mathrm{~mm}$ の 3 種 で，平滑試験片かよど図(B)，(C)のどとを孔を有す る 2 種類の試験片について行つたものである. $12 \mathrm{~mm}$ 試験片を基準として，耐人限度は $60 \mathrm{~mm}$ 圾験片で約 10〜25\%の減少を示しているが, 特に $12 \mathrm{~mm}$ と $30 \mathrm{~mm}$ との間に和ける減少の割合が大きい。 


\section{4. 寸法勃果に及ぼす種々の因子の影㗽}

耐久限度の寸法効果を求的疲労試験に扣にては, 寸法の異なつを試験片について全く同じ条件のもとに 実験するととが望ましいととはもちろんであるが，と のととは実際上なかなか园難なととである。何となれ ばそととえば大小 2 種の試験片を同一位羅より採取す るととはできないし，また試験中の試験片の温度上昇 も大小試験片に和々て相違してくるからである。また 而人限度に及尔す寸法効果は試験片の表面の仕上状態 によつて著しい影響を受けるものである．以下てれら の事項につ々て考察して見よう。

\section{a. 試験椣の回転速度と試験片表面の温度上昇}

一般飞疲労試験を行うとき，試験片の回転速度は一定 で行われるのが普通である，寸法効果の実験に和にて も。寸法の異なつ試験片につ々て同一の回転数で実 験するととが試験条件を一定にする意味に和にて望ま しいようス考えられる．ところが各種寸法の試験片に 同一の回転速度を与えるならば, 試験片の表面に発生 する熱忖寸法の大きい試験片ほど大きく，したがつて 試験片の温度上算は大きい試験片にど著しん。この温 度上犁の相違による耐久限度の值の変化はかなり重要 なものである。したがつて試験片が大きくなるほど， 試験機の回転数を和として温度上是を防ぐことが必要 となつて来る。をと立ば，H.F. Moore \& D. Morkovin ${ }^{5}$ )7) の実験で，試験片の寸法 $2,1^{3} / 4,1^{1} / 2$ inch 飞対して回転数 $400 \mathrm{rpm}, 1 ， 7 / 3$ inch K対しては $800 \mathrm{rpm}, 1 / 2$ inch $\mathrm{K} は 1200 \mathrm{rpm}, 1 / 4$ inch $\mathrm{K}$ は $2400 \mathrm{rpm}, 1 / \mathrm{s}$ inch Kは $3200 \mathrm{rpm}$ まをは $6000 \mathrm{rpm}$ とし，てれによつて試験片表面の温度をすべて $110^{\circ} \mathrm{F}$ （約 $43^{\circ} \mathrm{C}$ ) 以内反保ちえたと述べている.

b. 試験片表面の状態 第11図は R. Faulhaker ${ }^{2}$ ) による平滑試験片に和ける種々の表面仕上の状態《和 ける耐久限度の寸洗効果を示す。これによると寸法効 果は試験片表面の仕上状態によつてかなり大きな影響

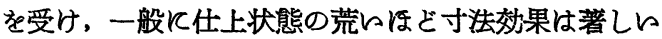
ことが判る.

H.F. Moore \& D. Morkovin ${ }^{15)}$ そよれば,すべて 試験片の表面はくが丁寧に仕上げても，その材料特 有のある荒さが残り，その微細な凹凸が丁度切欠のと とき効果を生し，その切欠の大きされよつて試験片に 寸洗动果による耐久限度の減少を生ぜしめると考充て ウる。しかして表面に全然层のない理想的な試験片を 仮定し，てれを flawless specimen と呼んでいる。す なわち，乙の flawless specimen では寸法勃果がな く，同一の材料では寸法が異なつても酎久限度は一定 であると考えている。

c. 素村よリの各種寸法試験片の採取位置 通常 一つの素材からあらゆる寸洗の試験片を採取するわけ
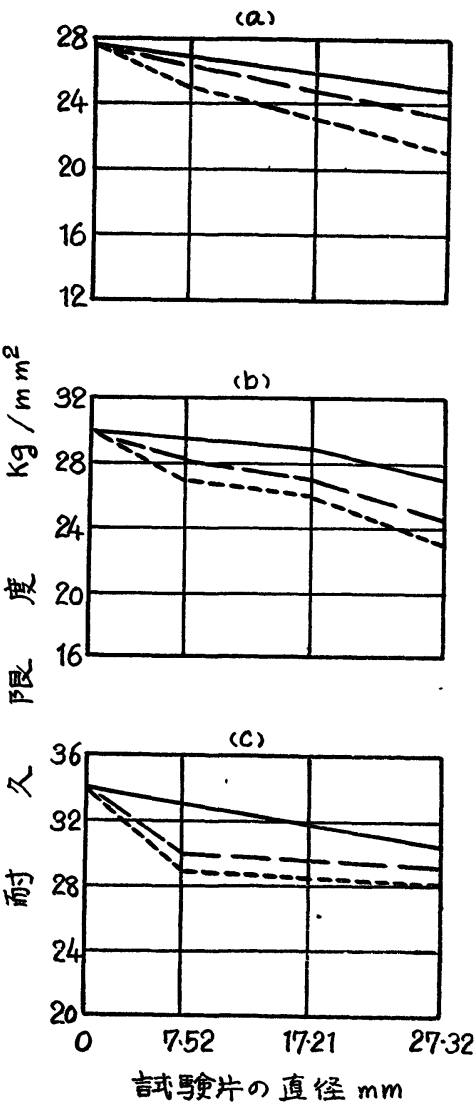

(a) $0.1 \% \mathrm{C}$ 炭类銷 $\sigma_{B}=41.5 \mathrm{~kg} / \mathrm{mm}^{2}$ (b) $0.3 \% \mathrm{C}$ 炭素知 $\left.\sigma_{B}=55.5 \mathrm{~kg} / \mathrm{mm}^{2}\right\}$ (R. Faulhaber) ${ }^{8}$ ) (c) $1 \% \mathrm{C}$ 炭絭细嗦华 一つヤ出し - - - 研㓣仕上 -...- - 旋盤仕上

第11図 回転曲げ疲労試験に和ける平滑試験 片の表面仕上の程度による耐久限度 寸法効果の相違

であるが，とのとき各盾寸法の訊験片をなるべく同じ 位置に相当した場所から取るととが望ましい，何とな

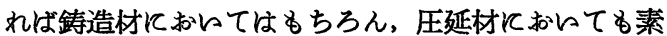
材の各部に扣にてその強度はかなり相違与るからであ る. H.F. Moore \& D. Morkovin ${ }^{5}$ ) は はこの試験片 の採取法にも注意して実験を行つている.

その他熱処理㹤, 加工法などにより耐久限度の寸法 勃果《影響が与えられるのは，他の疲労試験の場合と 同じであるが、これらは今啳の研究に待をねばねらぬ。

\section{5. 結・䨐}

以上が従来行われた痕労試験に和ける寸法効果の大 要である. 寸法効果の現象はまだその機構が充分明ら かにされて和らす，実験資料も比較的少ない。しかし， ここに展望した従来の実験結果より疲労試験に和ける 寸法効果がいか瓜どのものであるかの概蛒は知りうる

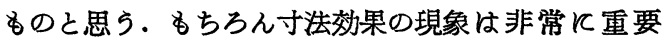
で，実際に侦用されるよらな大をな断面積をすつた試。 
験片につレて今後さらて数多くの研究の行われるとと が望まれる。

[附記] 従来寸法効果に関しては概してその影響を誇 大視する傾向があつたよう火思われる．著者の最近行 つた実験(1)あるいは最近の Hempel ${ }^{199} の$ 実験によれば 鋼に和にても寸法効果の影響は殆ど認められないとい ら結果になつて和り，注目すべきであると思ら。

注: -

1) E. Lehr, V.D.I., S 118 (1939)

2) R. Faulhaber, Stahl und Eisen, Heft 39, $110 \hat{o}$ (1933)

3) R. E. Peterson \& A M. Wahl, Trans. A.S.M.E., 53, A-146 (1936)

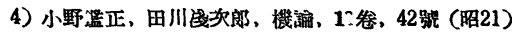

5) H. F. Moore \& D. Morkovin, ASTM, 42, 145 (1942)
6) E. Lehr, Prufen und Messen, V.D.I.Verlag, S. 153 (1937)

7) H. F. Moore \& D. Morkovin, ASTM, 43, 199 (1943)

8）河本實，西岡那夫、機論，18尞，65號、49（昭27）

9) 小野正致、機誌. 45替, 406 (昭17)

10) W. Kuntze u.W. Lu'simoff, Mittellungen der deutschen Materialprufungsanstalten, Sonderheft 32, 73 (1937)

11) H. F. Moore, ASTM, 41, 144 (1941)

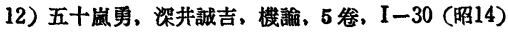

13) M. Hempel, K.W.I., S. 22 (1939)

14) C. E. Phillips \& R. B. Heywood, Applied Mechan'cs Proceedings, Vol. 165 (1951)

15) D. Morkovin \& H. F. Moore, ASTM, 44, 137 (1944)

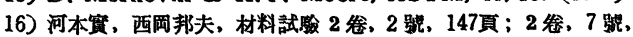
277 281頁.

17) F. B Jllenrath, Jahrbuch Luft-forschung, S. 147 (1938)

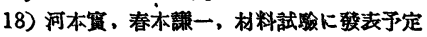

19) M. Hempel, Archiv f. Eisenhuttenwesen, 22, 11/12 (1951)

\section{$\mathrm{X}$ 線小角散乱による材料試験*}

\section{1. 序}

X線が材料試験の方法として利用せられたのは決し て新しいととではない.すねわち，その強い透過力を 利用した材料透視試験は衆知のように，かなり以前か ら実用的に大いに做用されてをたもので，今日では100 万ボルト級の高能力の物が直接生産工場飞据え付けら れてさ充々る.一方迴折現象を利用して材料の組織, あるには微視的立場からの粒子的構造の試験にも大に 飞利用され，またX線分光分析も可視，紫外線などの 分光分析はど盛んではないが，その色々の特長により 特殊な部門には大らに利用されている。更にまたX線 による結晶分析は分光分析や化学分析と全く異なり成 分元素を分析するととなく, 主としてデバイ環の特徴 から結晶性物質そのものをそのまま同定 (identify) するととに用的られ，定性はるちろん混合物の定量を も行らととがでをる。これらX線試験法はアメリカで は既爪 ASTM でも非常に重視したとえば結晶同定 のための数千種を数えるデータがカードに整理され， 現在もな和集録されつつある. 以上のようにX線は他 の物理測定法に比して, その応用範囲が著しく広く， かつ、それらは原理的にも全く異なつた形で用いられ ている.

これらのX線の利用法に更に加えて最近の十数年間 凡急に発展して来たのが X線小角敞乱法である。すな

\footnotetext{
* 原倯受付 昭和29年 3 月 31 日

**大陑大祭理學部

*4* 大阪大學工繁部
}

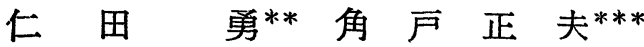

わちX線が $10 \AA ̊ 2000 \AA$ くらいの大をさの微粒子を 通過する時《通常の迴折現象より更に角の小さな範囲 《起る散乱現象を利用し，その粒子の大をさ，形，あ るいは集合の状態などを定量的に測定しようとするも のである.とれはコロイド, 煙霧質, 高分子, 䋊維, 蛋白質など，実際問題として学術上はもちろん工業上 《も, 材料試験と云う面加らも非常飞多種多様の応用 範囲を持ち，今後をすをす発展せしめられる余地があ るすの思われる．しかしながら他の多くの物理的測 定がそらであるように，小倩散乱もまたその理論的解 釈と被験物質和よび調べようとする目的の 3 者《は和 のずから限界があり，それらを良く検討するととがも ちろん大切となつてくる。

微粒子の測定につんては, 結晶体の時はそのデバイ 環の拡がりを利用する方法も古くから知られて和り， また浸透圧あるいは遠心沘降法などもコロイド，高分 子などの方面では従来からす良く使われ，更に電子顕 微鏡でははぼ直接的にはとんどあらゆる大きさのコロ イド粒子をす見ることができるよらになつてをた。し かしながら、これらはいずれの方法も資料の調製その 他にかなりの制限を受ける。をと皃ば特て電子顕徽鏡 では全く軲燥した物でなければならないととなどであ る. これ《対しX線小解散乱は液体, 固体, 結晶, 非 晶, またこれらの混在したものであつてもよく，しか

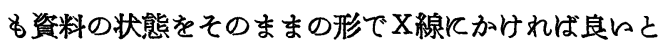
言う非常に大きい利点があり、なおその上沈降法や顕 